\title{
The Sanctity of the Village Green: Preserving Lord Denning's Pastoral Vision*
}

\author{
Steve Greenfield and Guy Osborn $\dagger$
}

"Village cricket is the oldest team-sport to have survived and adapted, still just about recognisable despite rolled wickets, overarm bowling, whites, pads, and a host of complex rules. It is this sense of a continuous tradition, of ancient links, and English pastoral that tugs at the heart of so many devotees today."1

The image of village cricket, the quintessential English game, conjures up images of peace, harmony and tranquillity. The community spirit built up over perhaps more than one hundred years is enshrined and embodied in the sporting activities that take place upon the Village Green. However, behind the idyllic facade may lie more serious neighbourly disputes between those who see the game of cricket as the focal point of village life and a tradition to be preserved at all costs, and those, perhaps newcomers to what may be a closed enclave, who begrudge its very existence. Such a dichotomy most recently appeared at Slough County Court when some of the residents of Jordans (a small village near Beaconsfield) sought an order enforcing Jordans Cricket Club to erect protective netting to shield their homes or to relinquish the right to play. ${ }^{2}$ Such cases have previously been considered by both the House of Lords ${ }^{3}$ and the Court of Appeal ${ }^{4}$ and have centred upon an attempt to balance the rights of an individual to enjoy the privacy and seclusion of his or her home and the public interest in protecting the environment and by preserving our playing fields in the face of

* The title owes a debt to Klinck "This other Eden': Lord Denning's Pastoral vision", (1994) O.J.L.S., Volume 14 No. 1.

† Steve Greenfield and Guy Osborn, Senior Lecturers, Centre for the Study of Law, Society and Popular Culture, University of Westminster School of Law.

I. R. Holt, Sport and the British (Oxford 1990). Max Sutton, noted in Klinck at 27, defines pastoral vision as referring to . . . a picture, literally an "Idyll", that represents at least the possibility of a good rural life. While the vision may express individual illumination, more typically it focuses upon some state of communal experience, showing people as lovers, friends, families, and neighbours, who tend animals and the land and yet find time to celebrate what matters most to them. . ".

2. Lacey \& Lacey v. Parker \& Bingle, County Court transcript, 12th May, 1994.

3. Bolton v. Stone [1951] I A11 E.R. 1078.

4. Miller v. Jackson [1977] A11 E.R. 338. 
mounting development, and by enabling our youth to enjoy all the benefits of outdoor games such as cricket and football."

Whilst the case of Lacey is of little value as a precedent it attracted much media attention and showed that the prescient approach of Lord Denning M.R., whilst dissenting in Miller, to be both influential and at one with the public's desire to preserve a little piece of a fast disappearing England. ${ }^{6}$

This article approaches the trilogy of cricket cases from two distinct angles. First, we examine the nature of the dispute and more precisely the conflict between the established order of the village and the "newcomer". Secondly, we analyse the application of settled legal principles to the facts and attempt to offer some conclusions as to the success of the courts in resolving a dichotomy imbued with a long cultural and social lineage.

\section{The nature of the disputes}

In all three cases the problems arose after land adjacent to the cricket grounds was developed for housing. In Bolton, cricket had been played on the ground of Cheetham Cricket Club since 1864 while the housing development on land, which had been previously owned by the cricket club, finished in 1910. An action was brought by a Miss Stone in both negligence and nuisance against the committee of the Cricket Club when she was struck by a cricket ball whilst standing on the highway adjacent to the ground. It was estimated at trial that over a period of some thirty years, since the development had been completed, a ball had been struck onto the highway on some six occasions. The plaintiff was hit by a straight drive which was estimated to have travelled some 100 yards to the point where Miss Stone was struck. The ball had pased over a 7 feet high fence which amounted to a 17 feet high barrier when the slope of the ground was taken into account. ${ }^{7}$

In Miller cricket had been played at Lintz, in County Durham, since 1905. In 1972 the plaintiffs bought a house in a recently built housing estate adjoining the ground where ". . . four years ago was a field where cattle grazed." "9 Lord Denning M.R. felt that it was the development itself that had caused the problem:

\section{Ibid p.345 per Lord Denning M.R.}

6. Judge Hague found the huge media attention bewildering noting that ". . . although this is a local dispute, it has nevertheless attracted a remarkable amount of attention from the national media. Quite why, it is difficult to know. Perhaps the subject matter touches the lives and stirs the emotions of many people. Perhaps it is just an entertaining diversion from the reports of tragedy, crisis and gloom which usually fill the newspapers. Perhaps it gives journalists and headline writers the opportunity to sharpen up (and mix) their cricketing and legal metaphors and puns. " County Court transcript, 'Supra. n.2', pp. 1-2. as will be seen throughout this piece, the judiciary are themselves not beyond such mixed metaphors and forced puns.

7. The name of the batsman is not recorded but this was an exceptionally powerful stroke. It was described in evidence by two senior members of the club as "altogether exceptional to anything previously seen on the ground".

8. Miller Supra. n.4 p.340 per Lord Denning M.R. He goes on to add that "the animals did not mind the cricket. But now this adjoining field has been turned into a housing estate." 
"I must say that I am surprised that the developers of the housing estate were allowed to build the houses so close to the cricket ground. No doubt they wanted to make the most of their site and put up as many houses as they could for their own profit. The planning authorities ought not to have allowed it. The houses ought to have been sited so as not to interfere with the cricket."'9

The relationship between the club and the plaintiffs was an uneasy one; initially several balls landed in the plaintiffs' garden and damaged tiles and brickwork which led to representations being made to the club. This resulted in the erection of a chain link fence that brought the total height of the plaintiffs' fence to over 14 feet. The club also asked batsmen to try and hit balls for four rather than six so as to avoid the possibility of further damage to the plaintiffs' property. Notwithstanding these precautions in the 1975 season 5 balls landed in the plaintiffs' garden, one of which narrowly avoided breaking a window of the room in which their son was sitting. Accordingly the family felt unable to remain in the house whilst the cricket was taking place and consequently they sought a remedy against the cricket club based upon negligence and nuisance.

In Lacey the basis of the plaintiffs' claim was that the intrusion of cricket balls onto their property was dangerous and as such was an unlawful interference with their property. As long ago as 1921 the management committee of Jordans Village Limited ${ }^{10}$ had anticipated the land being used for recreational purposes: " $\left.t \mathrm{t}\right] \mathrm{he}$ layout provides for a village green of three acres which will be laid out for sports and pastimes of various kinds." 'II

The cricket club had begun playing matches on this ground from the early $1920 \mathrm{~s}$ and at the time of the case there were 49 playing members of mixed ability, most of whom who had longstanding connections with the club and the community. In February 1988 the plaintiffs completed the purchase of their cottage, which faced the Green and which was at its most acute 55.5 yards from the nearest pitch. Judge Hague noted that it is the very nature of the game to attempt to hit the ball towards or over the boundary and that given the proximity of the pitch to the adjoining cottages some interference with property was inevitable. The actual propensity to interference varied between the different houses in different positions around the cricket square and the description of the issues showed a shrewd understanding of cricketing detail by the Judge:

"There is not much problem from a drive back over the bowler's head, or in the direction of long off or long on, or from (a) fine leg glance or a delicate late cut, or perhaps more elegantly (if the Cricket club will forgive me for saying

9. Ibid. at p.341.

10. The village had long associations with the Quaker movement. In 1920 some members of the movement bought 102 acres of land in the village and transferred part of that land (the Green) to Jordans Village Limited, a society created for the express purpose of creating a village community.

11. Lacey, Supra. n.2, at p.2. 
so) a snick through the slips or a miss by the wicketkeeper . . . the evidence was that it was leg side hits . . . (to deep mid wicket or deep cover point) . . . which tended to be the hardest and the most likely to be lofted, whether by a genuine hook or pull, or by the traditional one-foot-down-the-wicket cross bat slog into what is sometimes called "cow shot corner". A hard slog behind the square can certainly be played, but in village cricket it is a good deal more rare. Most shots going in that direction are the result of either nudges or glances, or of hooks and pulls which have been mis-hit or mis-timed, and as a result have less force. . . Even in first class cricket sixes over cover point or extra cover are relatively rare. ${ }^{12}$

It was not disputed that the position of the Lacey's cottage, which Judge Hague deemed to be at backward square leg to the right handed batsman, was one of the areas most likely to be in danger during a cricket match, although not in the "cow shot corner" that the Judge felt most vulnerable. ${ }^{13}$ There was evidence of actual damage to the houses surrounding the Green but there was no evidence of personal injury having been occasioned; since 1967 there had been only two incidents involving broken windows, both of which had been quickly replaced at the expense of the club. As regards the plaintiffs cottage the Judge found that at most the ball came into their garden on 5 or 6 times in a season, that these had primarily been at ground level and that there was no evidence of any damage being done to Linden Cottage in the past. As such, whilst there was a degree of risk such a risk was a very small one.

In addition, the club had taken a series of measures designed to further minimise that risk by instructing players not to play shots in that area, asking opposing captains to not put on bowlers who were likely to be hit in that direction and adopting a local rule that any ball hit into that portion of the ground on the full toss would count as 4 and not $6 .{ }^{14}$ The club had also looked into the possibility of moving their ground but this would have proved impracticable due to lack of suitable alternatives in the village. ${ }^{15}$

All the cases exhibit the common ground of having to balance the interests of the well established and traditional against those of "newcomers" with perhaps less conservative ideals. However a prime difference is that in Bolton the plaintiff suffered physical injury whilst in both Miller and Lacey although there were allegations of

\section{Ibid. at p.8}

13. The Judge's analysis went on to show his wherewithal as regards the current state of cricket when he went on to consider the potential vulnerability if a left handed batsman were at the crease which he felt was increased: " [Of course there are also left-handed batsmen who hit the ball hard. Mr Brian Lara recently reminded us of that in Antigua, and continues to remind us at Edgbaston if any reminder were needed]." Ibid. at p. 12 .

14. After the conclusion of the case the cricket club amended its rules so that any batsman hitting the ball into the garden was dismissed!

15. One possible alternative, Chalky Fields, needed levelling and redeveloping and the club would not have been able to play cricket for around three years whilst this work was done. 
property damage and possible fear of injury no actual physical injury had been suffered. In both the latter cases aspersions were cast upon the soundness of the plaintiffs' fears and the veracity of their complaints. An issue that is referred to throughout both Miller and Lacey is the relationship between the complainants, the cricket club and the other villagers; judicial sympathy for such complaints is strongly balanced by support for the established community traditions. the concept of the complainant as an "outsider" to the village and the social affairs of the community is further outlined by Fraser:

\footnotetext{
"Into this neighbourhood, this world of shared values and interpretations enters "the newcomer", the ideal and evil Other, threatening the peace and harmony, the very existence of the community. The newcomer is foreign, other, dangerous. Cricket is tradition, he is new; the villagers belong to the established practices of their cricket, he comes, inserts himself, violates their peace, threatens their very existence." 16
}

The problem in all three cases was for the judges to apply the established legal principles of nuisance and negligence to what is essentially a social and cultural dispute. In Lacey other villagers submitted evidence in support of the cricket club and these views were held by the Judge to be "Plain and sober and simple notions among the English people". In Miller Lord Denning M.R. explicitly recognised this area of the conflict and the position of the newcomer who seeks to upset the existing order of traditional village life and was cautious about utilising legal provisions to upset an existing status quo that had stood the test of time.

\section{The application of negligence and nuisance}

In Bolton the claim was based squarely in negligence and the High Court's dismissal of the claim had been reversed by the Court of Appeal. ${ }^{17}$ The House of Lords took a unanimous view that the respondent could not succeed in negligence because of the infrequency of cricket balls being hit onto the highway. Accordingly the possibility of a pedestrian being injured would not be anticipated by the reasonable man and thus no liability existed:

"it is not enough that the event should be such as can reasonably be foreseen. The further result that injury is likely to follow must also be such as a reasonable man would contemplate before he can be convicted of actionable negligence.

16. Fraser, The Man in the White is Always Right (Sydney, 1993), p.22. See further McArdle, "Governing Bodies: Sport, the body and $R$ v. Brown", Manchester Metropolitan University Working Paper in Law and Popular Cutrure, Series 1 No. 1. Referring to the Court of Appeal's approach in Miller, Fraser comments: "Consider the romantic image of merrie England we are being presented with here . . . A sporting tradition which has existed on that pitch since Edwardian times is now under threat from a 'newcomer', an invader whose selfishness could destroy the fabric of village life and lead to the arrival of new unpleasantries - a factory or housing development which surely ought not to be allowed to blight this pastoral scene," at p.23. 17. The respondent had sued in nuisance also but this had been dismissed at first instance. 
Nor is the remote possibility of injury occurring enough. There must be sufficient probability to lead a reasonable man to anticipate it. The existence of some risk is an ordinary incident of life, even when all due care has been, as it must be, taken." I8

The upshot of the House of Lords' decision was that the standard of care to be imposed was not an absolute one but was to be based on a series of factors. Whilst these factors undoubtedly include reasonable foreseeability this of itself was not to be the sole litmus test - issues such as the likelihood of harm occurring and the purpose of the act were important factors that also had to enter the evaluative equation. ${ }^{19}$ The point is, of course, that the entire equation is a fine balancing act and as Lord Reid observed this case was "not far from the borderline".

In Miller the plaintiffs brought an action against the club claiming damages for negligence and nuisance and sought an injunction to restrain the club from playing cricket on the ground. At first instance such an injunction was granted and the defendants appealed. Both Geoffrey Lane L.J. and Cumming-Bruce L.J. found that the club were liable in negligence as there was clearly a foreseeable risk that the plaintiffs would be injured by stray cricket balls and that it would be unreasonable to expect the plaintiffs to remain behind shutters or to leave their house whilst the cricket was on. Lord Denning M.R. dissented on this point on the grounds that the use of the ground by the club was eminently reasonable:

"To my mind it is a most reasonable use. Just consider the circumstances. For over 70 years the game of cricket has been played on this ground to the great benefit of the community as a whole, and to the injury of none." 20

This is effectively the same approach demonstrated in Bolton, in that Lord Denning M.R. is once again weighing up the social utility or purpose of the act in question in deciding whether the Cricket Club have fallen below the required standard of care - however the attempt of Lord Denning M.R. to preserve a little piece of British cultural history failed on this line. The crux of the case as far as the plaintiffs were concerned was essentially the issue of nuisance as the relief which they required was unavailable in an action for negligence. ${ }^{21}$ Here the judicial response was to refuse an injunction to prevent cricket being played, despite a finding that the club's activities amounted to an actionable nuisance, on the basis that the status quo should be preserved after balancing the interests of the individuals with the interest of the public at large:

18. Supra. n.3. per Lord Porter at 1081.

19. See further on this economic analysis of the law of tort, Posner (1972) 1 Journal of Legal Studies 29 and the approach of Hand J. in United States v. Carroll Towing Co. Inc. 159 F. 2d 19 (1947).

20. Miller, Supra. n.4 at 344.

21. As Lord Denning M.R. observed: "The books are full of cases where an injunction has been granted to restrain the continuance of a nuisance. But here is no case, so far as I know, where it has been granted so as to stop a man being negligent." ibid. at 343-g. 
"There is a contest here between the interest of the public at large and the interest of a private individual. The public interest lies in protecting the environment by preserving our playing fields in the face of mounting development, and by enabling our youth to enjoy all the benefits of outdoor games, such as cricket and football. The private interest lies in securing the privacy of his home and garden without intrusion or interference by anyone. . I am of opinion that the public interest should prevail over the private interest." 22

The good folk of Lintz were therefore allowed to continue to play their cricket on the Village Green, to continue the tradition started by their forefathers and to enable the traditions of the village to pass down to their own children in due course. The outsider or newcomer was once again given little sympathy when the judges evaluated whether or not to grant the order requested.

Lord Denning M.R.'s general approach is ably demonstrated by Lacey, where the plaintiffs argued that the intrusion of cricket balls onto their property amounted to an unreasonable interference with the use of their land. They sought an order that the cricket club erect nets, 25 feet high, in front of their cottage before each game and an injunction to prevent cricket being played on the Village Green if the protective nets were not erected. Although both nuisance and negligence were pleaded, it was agreed that the plaintiffs could not succeed in negligence if they failed in nuisance.

Judge Hague was not prepared to support Lord Denning M.R.'s radical view of Sturges v. Bridgeman ${ }^{23}$ expressed in Miller and followed the majority of the Court of Appeal on this point. ${ }^{24}$ It was therefore no defence that the Laceys' had "come to the nuisance"; he was nevertheless able to distinguish Miller on the basis that the risk of injury in the case before him was minimal:

"That makes Miller v. Jackson plainly distinguishable for, as I read it, it was the serious risk in that case that led the majority to hold that there as an actionable nuisance and there is no such serious risk in this case."'25

As there was no actionable nuisance there was no question as to the granting of an injunction, however, Judge Hague made a strong case, based on the principles laid out in Miller, that this would have been refused even had a nuisance been demonstrated to exist. ${ }^{26}$ This refusal was based on the discretion that the court exercises when considering whether or not to grant an injunction. The points that Judge Hague thought weighed against the granting of an injunction were; the inappropriateness of the nets, the fact that there was no real hardship to the plaintiffs, the offer of the cricket club

22. Ibid. at 345 .

23. (1879) 11 Ch. D. 852.

24. Lord Denning M.R. argued persuasively for a review of Sturges. "The building of a house does not convert the playing of cricket into a nuisance when it was not so before". Miller, Supra. n.4 at 344 .

25. Supra. n.2 at p.14. 
to erect window grills, that the plaintiffs had come to the nuisance and that the injunction would be damage to not only the cricket club but the interests of the village as a whole thus returning to the approach that Lord Denning M.R. effectively outlined in Miller.

\section{Conclusion}

Lord Denning M.R.'s original analysis is interesting for a number of reasons; not least because of the undercurrent of protecting a little piece of England and a cultural force that deters the folk of the village from turning to more destructive pastimes. The game of cricket is seen both as a microcosm of a utopian society and a clarion call for a return to the values that such a society espouses. The threat to this is embodied in the notion of "the foreigner", "the outsider", who has come to invade the sacred social text that is village cricket:

"The new, the foreign, the materialistic, all these nefarious elements threaten truth and community. They threaten the community like a virus for like a virus they are foreign. Unlike even a virus, however, the newcomer is not natural - he threatens cricket . . . Its values, fair play, gentlemanly conduct, "the spirit of the game", are not only natural, they are public values, constitutive of the social text of what it means to be English. In the final analysis, what the newcomer has done "just isn't cricket" ', 27

Whilst the judgment in Lacey is not as explicit on these themes the intimation of protecting the village interest is apparent. The evidence of others villagers is considered and the balancing of the private and public interest again weighs heavily in support of the collective against the individual. What Lacey does demonstrate is that the dichotomy between the established order and the newcomer is both an ongoing and a serious problem. To date the cases demonstrate that the judges will moderate the protection of individual property rights and uphold the collective rights of the majority to continue with established community activities and exercise their judgment with the avowed intention of preserving their own vision of what constitutes life in the community.

26. The main reasons given for the finding that no actionable nuisance existed were: " 1 . The playing of cricket on the village green is a reasonable and long established use. 2. The risk of serious injury is minimal and the interference with $\mathrm{Mr}$ and Mrs Lacey's enjoyment of their property is not undue. 3 . Such interference is the consequence of the character of the neighbourhood, ie the proximity of the village green. 4 . Whether the interference is unreasonable must be tested by the standards of average people and not the susceptibilities of $\mathrm{Mr}$ and Mrs Lacey. Although no means conclusive, the willing acceptance by others of comparable interference confirms my view that the interference in this case is not unreasonable." (Lacey Supra n.2.

27. Fraser, supra n.16, p.23. 